
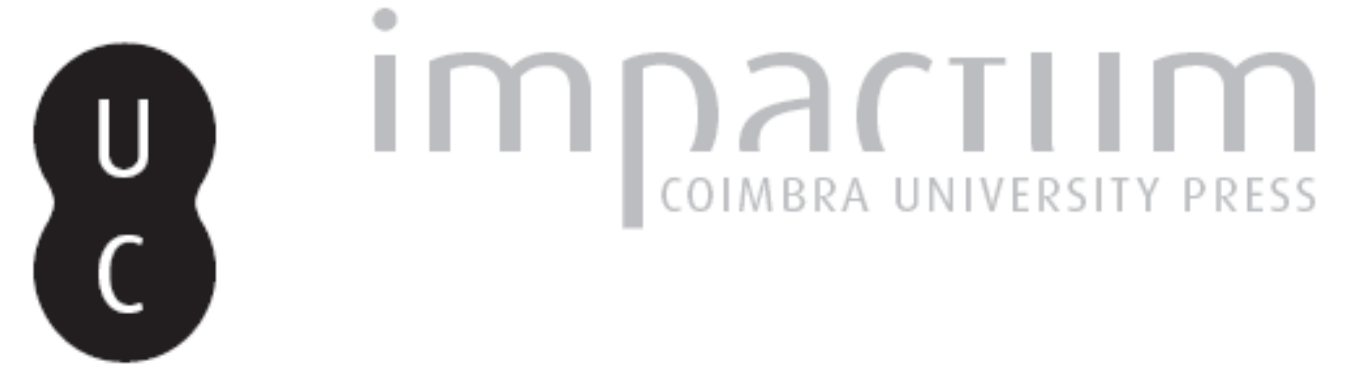

\title{
Antonio Sérgio queirosiano
}

\section{Autor(es): Reis, Carlos}

Publicado por: Imprensa da Universidade de Coimbra

URL persistente:

URI:http://hdl.handle.net/10316.2/45046

DOI:

DOI:https://doi.org/10.14195/2183-8925_5-1_7

Accessed : $\quad$ 26-Apr-2023 13:29:06

A navegação consulta e descarregamento dos títulos inseridos nas Bibliotecas Digitais UC Digitalis, UC Pombalina e UC Impactum, pressupõem a aceitação plena e sem reservas dos Termos e Condições de Uso destas Bibliotecas Digitais, disponíveis em https://digitalis.uc.pt/pt-pt/termos.

Conforme exposto nos referidos Termos e Condições de Uso, o descarregamento de títulos de acesso restrito requer uma licença válida de autorização devendo o utilizador aceder ao(s) documento(s) a partir de um endereço de IP da instituição detentora da supramencionada licença.

Ao utilizador é apenas permitido o descarregamento para uso pessoal, pelo que o emprego do(s) título(s) descarregado(s) para outro fim, designadamente comercial, carece de autorização do respetivo autor ou editor da obra.

Na medida em que todas as obras da UC Digitalis se encontram protegidas pelo Código do Direito de Autor e Direitos Conexos e demais legislação aplicável, toda a cópia, parcial ou total, deste documento, nos casos em que é legalmente admitida, deverá conter ou fazer-se acompanhar por este aviso.

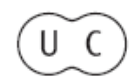




\section{REVISTA DE HISTÓRIA DAS IDEIAS 5}

\section{António Sérgio}

*

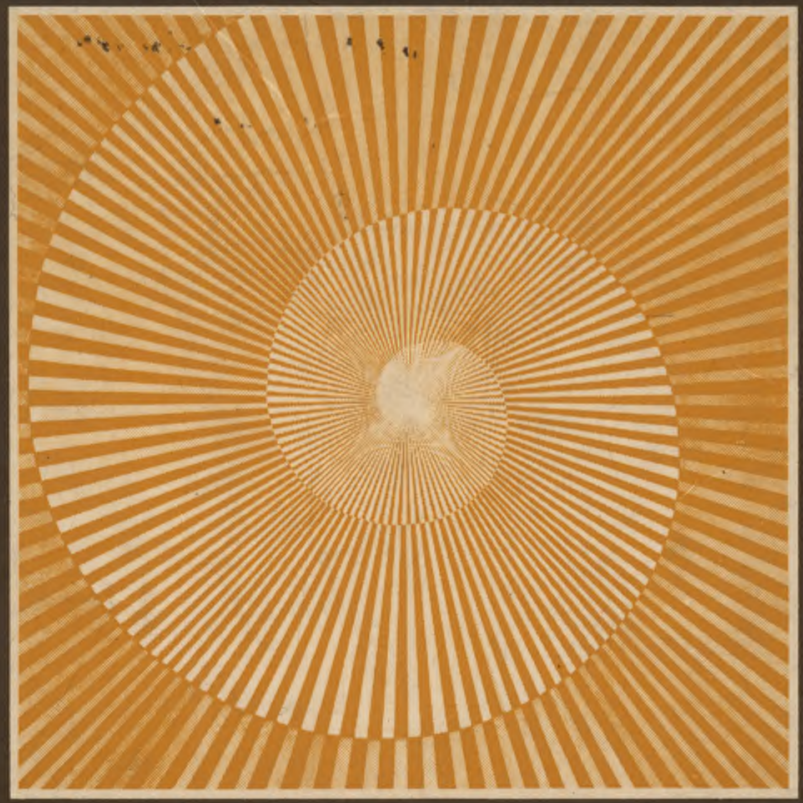

INSTITUTO DE HISTÓRIA E TEORIA DAS IDEIAS FACULDADE DE LETRAS 


\section{ANTONIO SÉRGIO QUEIROSIANO}

1. É sabido que a imagem que possuímos de um escritor e da sua produção literária não é neutra nem inocente. Para além de um fenómeno de implicações socioculturais (como as que determinam flutuações de popularidade de autores sujeitos a entronização cultural em certas épocas e, noutros períodos, a indisfarçável subalternização), a configuração dessa imagem é condicionada pela erosão que o tempo cultural arrasta e pelas leituras que nele vão decorrendo.

Eça de Queirós não escapa a esta lei: antes de tudo pela sua invulgar estatura estética, capaz de desencadear uma atenção considerável, mas também pela propensão crítica (quando não polémica) da sua obra, para mais marcada por uma diversidade de aspectos e componentes ideológicos desde logo polarizadores de controvérsia. Lembremos aqui, apenas de passagem, as reacções negativas que, até há não muito tempo, eram provocadas pelo alegado anticlericalismo d'O Crime do Padre Amaro ou d'A Relíquia - ou, num enquadramento oposto, a sua utilização abusiva como puros veículos de corrosão institucional; lembremos também que o romance $A C i$ dade e as Serras pôde, não raro, ser apresentado como palinodia de uma abominada postulação «estrangeirada» do jovem Eça ou que A Ilustre Casa de Ramires pode ocasionar interpretações que, ignorando o contexto histórico em que foi concebido e escrito o romance, bem como a sua organização interna, o assumam como instrumento difusor de um neocolonialismo algo serôdio.

Tudo isto é sabido e nada disto é original. A própria geração em que Eça se incorporou procurou valorizar a ima-

* Faculdade de Letras da Universidade de Coimbra. 
gem de Camões que melhor se ajustava aos seus desígnios políticos e ideológicos (o final d 'O Crime do Padre Amaro, redigido à beira do tricentenário da morte do épico, constitui um documento eloquente disso mesmo); noutro quadro histórico-cultural, coube ao movimento da Presença recuperar a geração de Orpheu para a notoriedade que o seu tempo não soubera reconhecerdhe e, mais perto de nós, o Neo-Realismo tendeu a distanciar-se do Realismo oitocentista que, na óptica neo-realista, trazia consigo as mazelas do reformismo proudhoniano.

Ora o Eça que hoje lemos não pode deixar de ser condicionado por uma espécie de pluridiscursividade crítica, feita do cruzamento, da complementaridade e até do desencontro das múltiplas «vozes» que dele têm falado. Um Mário Sacramento, um Alberto Machado da Rosa, um Ernesto Guerra da Cal, um António José Saraiva, um António Sérgio, são, entre muitas outras, algumas dessas vozes, capazes até, por sucessivas mediações, de atingirem o leitor não especializado, levando-o a procurar em Eça, antes de tudo, uma imagem não raro estereotipada: a do mestre da ironia, a do crítico de costumes, a do anticlericalismo sistemático, etc., etc.

O caso da crítica sergiana é, a todos os títulos, um caso peculiar. Ao 1er Eça, António Sérgio não o faz tanto com a exclusiva colaboração de um prisma metodológico particular, mas antes com base numa certa estratégia de reflexão, genericamente identificada com a propensão ensaística que imprime ao seu discurso; mas essa estratégia não pode deixar de ser marcada, como é óbvio, pelas dominantes do humanismo sergiano, que «não é só uma teoria do conhecimento, mas uma filosofia tendente à acção- à acção das acções que é o devir do homem pelo acto de intuir-se como ser espiritual e, por conseguinte, susceptível de emancipação total. Emancipar-se, sim, mas desde os grilhões de estruturas económico-sociais arcaicas e injustas e, portanto, desumanizantes, até à libertação das mais recônditas nebulosidades mentais que impedem ou obscurecem a assunção da realidade espiritual do homem, a qual se explicita mediante a ascese judicativa ao bem, à verdade e à beleza» 0 ).

Vale a pena, entretanto, insistir nas consequências que, ao nível dos percursos de leitura instituídos e dos resultados a que chegam, são arrastadas pelo ensaísmo, pelo «antidogmatismo e problemática, ou seja, [pela] recusa sistemática a

0) Joel Serrão, «Para uma apologia de António Sérgio», Portugueses somos, Lisboa, Livros Horizonte, s/d., p. 95. 
quaisquer verdades intocáveis», completada pelo «postulado de que a inteligência só ao nível do problema é libertadora e construtiva de novas relações» $\left({ }^{2}\right)$. Sabe-se, de facto, que o discurso ensaístico propende, por natureza, ao tentear de caminhos de reflexão inexplorados, à interpretação predominantemente intuitiva e à recusa de preconceitos limitativos do livre-exame; em António Sérgio, estas dominantes são acompanhadas pela reiterada afirmação (sincera ou irónica, não cabe agora decidir) de uma espécie de cautela no avanço da reflexão, o que confere ao seu estilo uma entoação inconfundível: expressões como "se não estou em erro», "se não estou iludido», "ao que podemos supor», "se não vou transviado», traduzem bem a consciência do carácter exploratório (e até, em certa medida, provisório) que é próprio do ensaio. Se a isto juntarmos o pendor polémico que a sua prática cultural revestiu - pendor que levou Eduardo Lourenço a afirmar que «contestar Sérgio parecerá.... uma forma de justiça imanente ou, pelo menos, o eco normal devido a uma palavra que viveu muito da impugnação de outras» $\left.{ }^{3}\right)$ - teremos apreendido os fundamentais vectores que condicionam as leituras sergianas da obra de Eça de Queirós. De tal modo que dificilmente nos apercebemos, nos ensaios consagrados ao autor d'Os Maias, das pausas ou silêncios de um diálogo travado entre duas vozes inextricavelmente confundidas: a do romancista cujo discurso é recordado e trazido para a cena da reflexão, e a do ensaísta cujo pensamento se vai configurando e impondo à custa dessa invocação, pelos meandros de um discorrer imparável — ou, para usarmos uma metáfora de sabor sergiano, «navegando à bolina» de argumentos aduzidos com uma vivacidade inconfundível.

2. Do exposto não deve inferir-se que o ensaísmo de Sérgio (e, em particular, os textos que dedicou a Eça) constitui um aglomerado de apreciações destituídas de critério

(2) Idem, ibidem, p. 106.

(3) Eduardo Lourenço, «Sérgio como mito cultural. É o autor de «Ensaios» um ensaísta?», $O$ Tempo e o Modo, 69-70, Março-Abril de 1969, p. 250. Neste artigo, E. Lourenço menciona, de passagem, alguns dos adversários de Sérgio: Sant'Anna Dionísio, Bento de Jesus Caraça, Abel Salazar, J. Gaspar Simões, A. José Saraiva, etc. . Que as polémicas em que $A$. Sérgio se envolveu não foram gratuitas ou inconsequentes, demonstrou-o Fernando Guimarães, quando sublinhou o significado do enfrentamento com Gaspar Simões, nos primórdios da constituição do Neo-Realismo (cf. F. Guimarães, $A$ poesia da Presença $e$ o aparecimento do Neo-Realismo, 2." ed., Porto, Brasília, 1981, pp. 100 ss.). 
orientador. Pelo contrário: no Eça que preferiu, nos aspectos da sua produção literária que privilegiou, Sérgio activa, desde logo, pelo menos de forma implícita, um certo prisma de abordagem, genericamente ligado ao projecto humanista citado.

De facto, a grande preocupação que atravessa as leituras sergianas de Eça é a de valorizar os componentes éticos que integram o universo de ficção e, em particular, o comportamento das personagens. A educação, o ócio, a energia vital (ou a sua ausência), o impulso transformador que o indivíduo manifesta, o seu auto-controlo ou as tentativas de o conquistar, a representatividade histórico-social dos gestos e reacções das personagens, numa palavra, a sua dignidade e plenitude humana (conseguida ou frustrada, almejada ou ignorada), são os fundamentais temas que dominam o percurso de Sérgio através da ficção queirosiana.

Naturalmente que, valorizando estes componentes, o ensaísta incorre num risco: o de considerar que «a literatura tem sobretudo um papel de mediação que é de resto indispensável ao ensaio. Esta mediação deve ser entendida como necessidade de o ensaísta se servir da literatura unicamente como ponto de partida....» $\left({ }^{4}\right)$. Ora é sabido que um tal comportamento implica perigos de ordem metodológica e desvios epistemológicos por demais evidentes. São, por exemplo, os que se nos deparam quando encontramos análises da obra de Cesário que, «atravessando» um discurso (o poético) muito longe de ser transparente ou inócuo, procuram reconstituir, numa óptica preferentemente documental, o universo urbano de fins do século XIX; ou os que se deduzem de leituras das Viagens de Garrett, interessadas apenas nos incidentes histórico-políticos que afloram num texto dotado de uma certa configuração estrutural, de uma peculiar coloração estilística e de elementos simbólicos que interditam uma abordagem puramente referencial; ou ainda, no plano da produção literária, os equívocos inerentes a postulações programático-ideológicas que, no contexto do Realismo socialista ou do Neo-Realismo português, solicitam à obra literária o exercício de funções eminentemente injuntivas e de prioritária intervenção sociocultural.

Tudo isto corresponde ao ignorar de vectores que configuram o estatuto de autonomia próprio da obra literária, segundo o qual «a obra é a lei de si própria na medida em que, ao construir-se vai construindo os seus próprios limi-

$\left({ }^{4}\right) \quad$ Carlos de Oliveira Coelho, «Ambiguidade e ironia em António Sérgio», Critério, 3, Lisboa, 1976, p. 37. 
tes» $\left({ }^{5}\right)$; uma autonomia estreitamente relacionada com a peculiar dialéctica semântica que, no dizer de Galvano della Volpe, preside à «circolazione del pensiero storico (scientifico) nella poesia», de tal modo que, em tal circulação, «il ripensamento poetico, cioè polisenso, di significati nella fattispecie storici conserva e muta ad un tempo tali significati: li conserva nei loro valori letterali-materiali, sviluppati si ma anche inglobati nei loro valori univoci...., e li muta con l'in* tegrarli di ulteriori sensi o valori nella e per la formulazione pluralistica illimitata di nomi-frasi propria del polisèmo o polisenso: di modo ehe è per il medio — squisitamente linguístico - dei valori onnitestuali ehe i valori onnicontestuali, cioè i significati univoci, storici, in questione, si trasvalutano in significati contestuali-organici, poetici....» $\left(^{6}\right)$.

3. Do nosso ponto de vista, trata-se sobretudo de averiguar como (e se) o ensaísmo de António Sérgio, no caso concreto da abordagem de Eça, torneou os riscos a que acima nos referimos; por outro lado, importa saber também em que premissas Sérgio se apoiava, de um ponto de vista metodológico e operatório, ao empreender a leitura da ficção

$\left(^{5}\right)$ P. Macherey, Para uma teoria da produção literária, Lisboa, Ecl. Estampa, 1971, p. 54. Atente-se, entretanto, na ressalva operada por Macherey: «Não devemos porém confundir autonomia com independência. A obra institui a diferença que a caracteriza no acto de estabelecer relações com o que lhe é extrínseco: doutra maneira, não teria qualquer realidade, seria ilegível e mesmo invisível. Igualmente não se deve, a pretexto de exorcizar qualquer tentativa de redução, considerar a obra literária à parte, como se constituísse por si mesma uma realidade completa: absolutamente separada do que a rodeia, não seria possível compreender a razão da sua aparição. Passaria a não ter qualquer razão de existir e seria como que o produto duma epifania radical» (ob. cit., p. 55); cf. também E. Balibar e P. Macherey, «Sobre a literatura como forma ideológica. Algumas hipóteses marxistas», in M. Alzira Seixo (ed.), Literatura, Significação e Ideologia, Lisboa, Arcádia, 1976, pp. 40 ss.

$\left.{ }^{(}\right)$Galvano della Volpe, Critica del gusto, 3.' ed., Milano, Feltrinelli, 1971, p. 83. É no desenvolvimento desta concepção que se encontram as reflexões acerca das relações homológicas entre a obra literária e a vida social: "Cuando se hallan relaciones significativas, o aún mejor, homologi as verdaderas y propias (como precisamente sostiene Goldmann), entre las estructuras de la vida económica y ciertas manifestaciones literárias como la novela de personajes, tales relaciones pueden servir para aclarar el carácter social de la obra, para individualizar al autor colectivo en un grupo social del que el escritor individual no es más que el portavoz, y para demostrar que justamente las estructuras de ese grupo social (y no las de la psiquis individual del escritor) son las que se reflejan en la estructura de la obra» (F. Rossi Landi, El lenguaje como trabajo y como mercado, Caracas, Monte Avila Editores, 1970, p. 154). 
narrativa queirosiana, uma vez que esse posicionamento pode ter afectado consideravelmente a imagem de Eça que os seus escritos nos legaram.

Por aqui pode observar-se, desde já, que o que em especial nos interessa, neste momento, são os fundamentais textos de Sérgio sobre a obra de Eça, ou seja, os que se encontram nos Ensaios: uma reflexão relativamente breve suscitada por um prefácio de Agostinho de Campos; um ensaio que procura estabelecer os elos de ligação e as marcas de distanciação entre o protagonista d 'A Ilustre Casa de Ramires e personagens de obras de Goethe e Voltaire (designadamente Wilhelm Meister e Candide); finalmente, um longo texto acerca daquele que a Sérgio se apresenta como o problema nuclear vivido por diversas personagens de Eça: o Tédio do Ócio $\left({ }^{7}\right)$.

Não é por acaso (e muito menos por força de critérios de extensão material) que atribuímos a estes estudos um certo destaque. Fazêmo-lo, porque neles estão representados os dois aspectos mais relevantes da abordagem a que Sérgio sujeitou a ficção queirosiana: em primeiro lugar, as linhas de força metodológicas em que se estribam as leituras elaboradas, as quais sobretudo transparecem nos dois primeiros ensaios mencionados; em segundo lugar, porque neles (mas com maior nitidez nas «Notas sobre a imaginação....») se definem os vectores interpretativos que configuram o Eça que as reflexões de Sérgio nos transmitiram.

Curiosamente (mas não casualmente) o tomo III dos Ensaios faculta-nos um outro texto muito importante para apreendermos o que António Sérgio propunha como estraté-

$\left({ }^{7}\right) \quad$ Respectivamente: «Eça de Queirós e a sociedade portuguesa (A propósito de um prefácio de Agostinho de Campos)», Ensaios, tomo III, 2. " ed., Lisboa, Liv. Sá da Costa, 1972, pp. 130-139 (o prefácio em causa é o que A. de Campos escreveu para a obra Eça de Queiroz. Antologia portuguesa, Paris-Lisboa, Aillaud \& Bertrand, 1922-1923, 2 vols. De acordo com a Bibliografia queirociana do Prof. Guerra da Cal, trata-se da primeira antologia em língua portuguesa inspirada pela obra de Eça; cf. Lengua y estilo de Eça de Queiroz. Apêndice: bibliografia queirociana sistemática y anotada e iconografia artística del hombre y de la obra, tomo I, Coimbra, Acta Universitatis Conimbrigensis, 1975, p. 583); "Guilherme Meister, Cândido e Gonçalo Mendes Ramires", Ensaios, tomo IV, 2. ${ }^{\text {a }}$ ed., Lisboa, Liv. Sá da Costa, 1981, pp. 175-189; "Notas sobre a imaginação, a fantasia e o problema psicológico-moral na obra novelística de Queirós», Ensaios, tomo VI, Lisboa, Liv. Sá da Costa, 1971, pp. 53-120 (estudo originalmente publicado no Livro do Centenário de Eça de Queirós, organizado por Lúcia Miguel Pereira e Câmara Reis; Lisboa-Rio de Janeiro, Edições Dois Mundos, 1945, pp. 449-502); a estas edições dos Ensaios referir-se-ão todas as citações. 
gia de crítica literária: trata-se do prefácio da primeira edição do referido tomo III, prefácio esse analisado já num artigo que David Mourão-Ferreira consagrou ao autor dos Ensaios $\left.{ }^{8}\right)$. Do que nesse texto se trata e de explanar um conjunto de concepções que, em princípio, servem de substrato metodológico ao ensaísmo de Sérgio, quando debruçado sobre o fenómeno literário. Mas não é apenas nesse aspecto que o prefácio em questão nos interessa: é também porque nele esboça-se um projecto de trabalho que a prática ensaística nem sempre preencheu. E nesta oscilação entre o que se cumpriu e o que se traduziu em desvio das propostas delineadas, podemos encontrar algumas explicações para a singularidade e para o cariz polémico das leituras queirosianas de Sérgio.

4. Quando declara que «em vez.... de um jogo de imagens, ou de acções, ou de caracteres, dá-nos a crítica um enredo de ideias, que são provocadas pela obra de arte» $\left({ }^{9}\right)$, António Sérgio abre três pistas de trabalho simultâneas e em certa medida complementares: uma, que propende a valorizar a dimensão ideológica da obra literária (não se esqueça que é a literatura que aqui nos interessa), talvez em detrimento de elementos temáticos ou de componentes predominantemente técnico-literários (procedimentos compositivos, elaboração estilística, etc.); outra, que procura de certo modo compensar a primeira, quando se refere ao «enredo de ideias» desvelado pela crítica, ou seja, à estruturação de uma informação ideológica que assim tende a ser encarada como domínio sistemático e não aleatório; finalmente, a mais significativa (no plano teórico) das pistas de trabalho mencionadas é a que decorre do afirmar-se que as ideias são «provocadas pela obra de arte». Não cabe agora saber se a asserção é correcta - parece-nos que só parcialmente o é, uma vez que obra artística e contexto sociocultural (incluindo as suas potenciais dominantes ideológicas) interagem, num processo de condicionamento dialéctico - mas sim de sublinhar a importância de um seu aspecto particular: o facto de a afirmação citada denunciar uma concepção não finalística da literatura, de tal modo que a esta não compete erigir-se em puro espaço de representação de informações ideológicas previa-

$\left.{ }^{8}\right) \quad$ Cf. «António Sérgio crítico literário», Sobre Viventes, Lisboa, Pub. Dom Quixote, 1976, pp. 137-165 (refundição do estudo originalmente publicado no Jornal de Letras e Artes, n. ${ }^{\mathbf{0}} \mathbf{2 0}, \mathbf{2 1}$ e 24, em Fevereiro e Março de 1962 e depois integrado em Motim Literário, Lisboa, Verbo, 1962, pp. 38-64).

C) Ensaios, tomo III, p. 10. 
mente determinadas, mas antes participar num amplo movimento de produção ideológica, cujo teor pluridiscursivo transcende o livre arbítrio do escritor $\left({ }^{10}\right)$.

Um segundo aspecto deste «programa crítico» liminarmente delineado por António Sérgio pode provocar alguma controvérsia. De facto, logo depois de consignar a propensão ideológica de que, na sua concepção, o acto crítico se reveste, o autor dos Ensaios interroga-se: "Não será a crítica também uma arte - a arte das artes, ou a arte sobre artes?» E em termos mais convictos acrescenta que se lhe afigura "absurda a distinção de críticos e de criadores», para concluir: «O verdadeiro crítico é um criador - criador de ideias e de doutrinas críticas» $\mathrm{O}^{1}$ ).

Deixando agora de lado o matiz idealista que perpassa nas últimas palavras citadas (matiz que concorda, aliás, com a já comentada concepção da obra artística como geradora de ideias), parece-nos necessário observar que o discurso de Sérgio tende a inflectir o rumo inicialmente imprimido às suas afirmações. Por outras palavras: não se trata propriamente de postular uma crítica de cunho estético (que aproximaria a concepção sergiana do impressionismo de um Anatole France ou de um Jules Lemaître, tão estimulante, em certos aspectos, mas carecida da componente pedagógica que Sérgio persegue), mas antes de lhe conferir um estatuto próprio, uma dignidade cultural e uma especificidade paralela à do fenómeno artístico, mas não incomunicável com ele.

Isso mesmo ressalta de uma outra passagem do prefácio que temos vindo a citar: "As ideias críticas ocorrem ao crítico num estado de verdadeira inspiração artística (como as ideias poéticas, ou as musicais), e vão-se organizando em sistema de carácter arquitectónico,- como as do poeta se organizam em canto, as ideias do pintor se organizam em

$\mathrm{C}^{\circ}$ ) Recordemos as seguintes palavras de Bachtin: «II prosatore-romanziere non estirpa le altrui intenzioni dalla lingua pluridiscorsiva delle sue opere e non distrugge gli orizzonti ideologico-sociali (i mondi grandi e piccoli) ehe si rivelano al di là delle lingue della pluridiscorsività, ma introduce queste intenzioni e questi orizzonti nella propria opera. II prosatore si serve delle parole già abitate da intenzioni sociali altrui e le costringe a servire le sue nuove intenzioni, a servire un secondo padrone. Perciò le intenzioni dei prosatore si rifrangono, e si rifrangono con angoli diversi, a seconda delle estraneità, della densità, dell'oggettivazione ideologico-sociale delle lingue rifrangenti della pluridiscorsività» (M. Bachtin, Estética e ro-

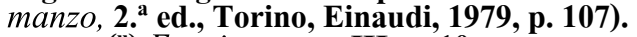

(") Ensaios, tomo III, p. 10. 
quadro, e as ideias do músico, em sinfonia» $\left({ }^{12}\right)$. Não parece abusivo inferir da propensão sistemática que a crítica deve cultivar, uma implícita preocupação com a sua circulação cultural, de acordo com o já aflorado pendor pedagógico que em Sérgio se reconhece: deste modo, funcionando como indispensável complemento judicativo do fenómeno literário $\left({ }^{13}\right)$, a crítica exerce esse efeito de feedback que modernamente lhe foi reconhecido pela sociologia da literatura de um Escarpit, assim participando, distanciadamente e de forma mediata, no processo de produção literária. O que não anda longe de uma concepção intertextual das práticas literárias, isenta de preocupações relativamente à intenção do escritor ou às suas fontes secretas e claramente traduzida nestas palavras: «A crítica fornece o ambiente de ideias em que a obra de arte se desenvolverá......... De forma directa ou reflexamente, as

concepções do crítico encaminham o artista, e a poesia de um Garrett pressupõe um Schlegel, como o romance de um Queirós pressupõe um Comte, um Taine, um Renan e um Proudhon» $\left({ }^{14}\right)$.

5. Dir-se-á que, afinal, falta às directrizes explanadas por António Sérgio a sistematização (lembre-se que ele mesmo falou em «sistema crítico») que atribua a tais directrizes a solidez de que carecem as orientações metodológicas com aspirações de eficácia. De facto, é assim, mas é justo que se diga que dificilmente seria de outro modo.

(12) Ensaios, tomo III, pp. 10-11. Consciente da especificidade do acto critico, Sérgio acrescenta, em nota, palavras que, como veremos, nem sempre estarão presentes no decurso do seu relacionamento com as obras literárias: «Filosofia a propósito de obras de arte não é critica de arte: é Filosofia; e ninguém se lembraria, por exemplo, de dar o nome de Oceanografia à meditação de Guyau a propósito do oceano, no Esboço de Uma Moral sem Obrigação nem Sançầ» (loc. cit. p. 19).

(13) Atente-se nas seguintes palavras: «Ao que suponho, é a acção permanente da boa critica o que conserva viva uma obm de arte. Livro que não é lido, não é livro que exista; e as obras máximas, se são sempre lidas, - e se chegam ao apreço do grande público, - é porque a critica as conseguiu impor. Esse «grande público» é um grande cego, e tende por natureza para uma arte medíocre; é ao medíocre, por via de regra, que ele dá o êxito imediato $e$ largo.

A crítica dá vida ao que merece vida, conservando em torno das grandes obras a atmosfera do interesse e da admiração. É por virtude da acção da crítica que a arte mais alta se não perde e afunda, submersa para sempre no oceano imenso dos artistas medíocres ou dos charlatães».

$\mathbf{(}^{\mathbf{1 4})}$ Ensaios, tomo III, pp. 11-12. 


\section{Antonio Sérgio}

Repare-se que Sérgio discorre sobre o assunto numa época (o prefácio em análise é datado de 1932) em que os estudos literários estavam ainda longe de conhecerem o desenvolvimento e rigor teórico-conceptual que hoje atingiram. Além disso, o autor dos Ensaios tendia a privilegiar (por formação, por natureza ou por pura "atitude ensaística», não cabe agora saber) um eelectismo inteiramente inadequado a rígidas imposições operatórias, eelectismo de resto algo desajustado da desejada especificidade do acto crítico: "Todas as fórmulas, todos os métodos, todos os sistemas nos parecem legítimos, desde que os empregue uma inteligência crítica que seja inteligência, e portanto crítica; pelo contrário, não existe método nem sistema crítico que sejam utilizáveis mecanicamente por um homem pobre de criaçãoo mental» $\left({ }^{15}\right)$.

$\dot{E}$ preciso notar, entretanto, que por muita convicção que se ponha nas palavras citadas ou por muito coerentes que elas sejam, no quadro de um pensamento e de uma prática cultural precisa, tais palavras não são inconsequentes. Elas traduzem uma certa estratégia de aproximação do objecto de estudo (neste caso, a obra de Eça) que em última instância se define como causa primeira do sucesso ou do insucesso de uma tal aproximação; e justamente pensamos que, no que toca à literatura queirosiana, essa estratégia conduziu a uma limitação considerável do objecto de análise, não só por força dos domínios de reflexão que Sérgio perfilhou, mas também pelos termos em que a citada reflexão se concretizou.

$\mathrm{Se}$ atentarmos no breve texto que Sérgio escreveu «a propósito de um prefácio de Agostinho de Campos» (Ensaios, tomo III), depararemos ainda com considerações mais da esfera do metodológico do que da área interpretativa propriamente dita. De facto, o que aí está em causa é saber como (e até onde) 1er Eça; um Eça a que, como é evidente, não é difícil aplicar uma leitura sintonizada como o princípio de que «de qualquer autor.... parece legítimo investigar (sem prejuízo da admiração literária) a sua influência na sociedade, e quais a justeza e profundidade das suas ideias sobre ela» $\left({ }^{16}\right)$. Daqui a uma leitura predominantemente (ou até exclusivamente) documental de uma obra erigida sobretudo em espaço de afloramento de fenómenos sociais e de informações ideológicas, vai uma distância muito curta.

É verdade que Sérgio ressalva a componente literária (cf. o parênteses «sem prejuízo da admiração literária»); é

(15) Ensaios, tomo III, p. 12.

(fif) Ensaios, tomo III, p. 131. 
verdade também que previamente afirmara a legitimidade de «todos os pontos de vista.... para estudar qualquer objecto» $\left({ }^{17}\right)$. Em nosso entender, no entanto, essas precauções podem não ser suficientes, por eventualmente se manifestarem incapazes de evitarem o risco operatório já esboçado no que se afirmou: a hipertrofia de componentes parcelares da obra literária (neste caso, os elementos de configuração social), independentemente da sua integração na totalidade orgânica a que pertencem, incluindo as estratégias discursivas que a esses componentes conferem uma peculiar configuração e impacto pragmático.

Naturalmente que isto não autoriza a que se pense que advogamos uma leitura da ficção de Eça inteiramente desinteressada da representatividade social que nela se plasma. Fazê-lo, seria ignorar não só o projecto queirosiano de reforma social e cultural (o próprio Sérgio invoca, a este propósito, o testemunho inequívoco do escritor $\left({ }^{18}\right)$ ), mas também a função de ideologema («la fonction qui relie les pratiques translinguistiques d une société en condensant le mode dominant de pensée» $\left({ }^{19}\right)$ ) que à literatura pode caber; e esta, por sua vez, relaciona-se directamente com a já citada pluridiscursividade ideológico-social em que o discurso literário participa $\left({ }^{20}\right)$. Só que uma tal participação decorre no qua-

$\left({ }^{17}\right)$ Ob. cit.y p. 130. Trata-se, aliás, de uma noção reafirmada num breve depoimento publicado no suplemento «Das Artes-Das Letras» (n. ${ }^{\circ}$ 267) do jornal O Primeiro de Janeiro, de 27 de Setembro de 1944: «Há muitos aspectos, sem dúvida alguma, sob os quais vale a pena considerar o Eça de Queirós e o Oliveira Martins: - o aspecto histórico, o biográfico, o literário-estético, o psicológico, o pedagógico, o social, etc. A meu ver, todos os pontos de vista são igualmente legitimos, e a única coisa que não é legítima é transferir para o domínio de um dos pontos de vista a qualidade do juízo a que se foi levado ao estudar a obra sob outro ponto de vista», p. 3.

(18) Cf. Ensaios, tomo III, pp. 134-135.

(19) J. Kristeva, Recherches pour une sémanalyse,

Paris, Seuil, 1969, p. 60.

$\left({ }^{20}\right)$ Numa fase relativamente primordial de reflexão, V. N. Voloshinov falou da dimensão social que todo o enunciado comporta, nos seguintes termos: "Il est donc impossible de comprendre comment se construit un énoncé quelconque, eût-il l'apparence de l'autonomie et de l'achèvement, si on ne l'envisage pas comme un moment, comme une simple goutte dans ce fleuve de la communication verbale dont l'incessant mouvement est celui-là même de la vie sociale et de l'Histoire» (Apud T. Todorov, Mikhaïl Bakhtine le principe dialogique suivi de Ecrits du Cercle de Bakhtine, Paris, Seuil, 1931, p. 238). Comentando esta fase de reflexão do Círculo $^{\wedge}$ de Bakhtine, Todorov observou: «On sent que la socialité de l'énoncé convient bien aux intentions explicitement marxistes de Volochinov/Bakhtine au cours de cette période; il serait selon lui (comme auparavant pour Medve- 


\section{Antonio Sérgio}

dro de uma especificidade (modos e géneros literários, coerções periodológicas mais ou menos discretas, procedimentos simbólicos e retóricos, etc.) que só uma concepção especular e primariamente materialista do fenómeno literário poderia subalternizar: é porque pretende tornear esses riscos que, por exemplo, Michel Zéraffa afirma que «só em aparência a maioria das grandes obras romanescas contemporâneas estão isoladas do mundo real pela sua tecnicidade, que o escritor voluntariamente toma visível. De facto, as diversas formas do monólogo interior.... são as traduções de um discurso social, ideológico, moral, religioso (e mesmo económico, no que respeita a Dos Passos), doravante rompido. E é a verificação dessa ruptura que o romancista quer fazer perceber ao leitor, sem o que a sua obra não seria realista» $\left({ }^{21}\right)$.

Se insistimos na importância deste excurso de natureza teórico-metodológica, é porque nos parece que ele permite distinguir, no Sérgio queirosiano, o que se nos apresenta clarificador de sentidos fundamentais da obra de Eça, do que nessa clarificação se manifesta precário ou metodologicamente inconsistente. Por outras palavras: não se põe em causa a pertinência da reflexão sergiana, no sentido de valorizar em Eça as potencialidades críticas da sua intervenção cultural $\left({ }^{22}\right)$. No contexto da actividade cultural protagonizada por Sérgio, nos primórdios do obscurantismo fomentado pelo consulado salazarista e em sintonia com uma propensão polémica a que já fizemos referência, parece-nos perfeitamente legítima a valorização do social em Eça, contra qualquer esboço (voluntário ou involuntário) de ofuscação desse componente crucial. Julgamos, no entanto, que o percurso trilhado pelo autor dos Ensaios não é isento de riscos de equívoco, quando verificamos que esse percurso se rege pela aceitação (até, em certa medida, pela afirmação) da dicotomia implícita nestas palavras: «O que nos parece importante em Quei-

dev/Bakhtine) aussi néfaste d'oublier les médiations qui rapportent le social au linguistique, que d'ignorer l'existence même de cette relation" (loc. cit., pp. 71-72).

(21) M. Zéraffa, Romance e sociedade, Lisboa, Estúdios Cor, 1974, pp. 159-160. Atente-se também nas seguintes palavras de Pierre V. Zima: «L'œuvre d'art digne de ce nom (la «grande ouvre» Goldmann) ne reflète pas, ne reproduit pas immédiatement les faits sociaux, les structures idéologiques, mais assume une fonction à la fois cognitive et critique en rendant transparente une réalité apparemment chaotique» («Litterature et société: pour une sociologie de l'écriture», in A. Kibédi Varga (ed.), Théorie de la littérature, Paris, Picard, 1981, pp. 286-287).

$\left.C^{2}\right)$ Cf. A. Sérgio, Ensaios, tomo III, p. 133. 
rós, é discutir a justeza e profundidade da sua crítica social,- - sem prejuízo [algum] da literatura, do elogio que todos devemos àquela forma maravilhosa, que se lề com auges de admiração»» ${ }^{23}$. Veremos, pela análise de outros contributos de António Sérgio, se são infundados os nossos receios.

6. O ensaio que António Sérgio parcialmente consagrou a Gonçalo Mendes Ramires constitui uma decisiva incursão no domínio do interpret ativo, na tentativa de salientar algumas das dominantes semânticas presentes nas obras de Eça. Isto não quer dizer, no entanto, que o ensaio em questão se isente por inteiro de incidências metodológicas que, nem porque apenas implícitas, são menos dignas de realce.

De facto, ao relacionar Gonçalo Ramires (o seu perfil psicológico, o seu percurso existencial, os seus anseios e limitações) com Wilhelm Meister e Candide, Sérgio não perfilha a solução cómoda e algo «detectivesca» da denúncia de fontes inspiradoras. Aparentemente consciente de que a produção literária se concretiza num amplo espaço de circulação, absorção e transformação das mais diversas informações culturais, António Sérgio preocupa-se tanto com as semelhanças entre as personagens como com as suas diferenças relativas, margem de afirmação de uma singularidade que lhes confere $\mathrm{o}$ estatuto de individualidades claramente demarcadas.

Por outro lado, ao debruçar-se sobre o protagonista d 'A Ilustre Casa de Ramires, António Sérgio desvela algumas das grandes preocupações que hão-de desabrochar no ensaio publicado no tomo VI, ou seja, o significado ético-ideológico de uma personagem determinada, cuja análise de certo modo é colocada ao serviço do projecto sergiano de reforma humanista dos costumes e das mentalidades. De facto, o que em especial o preocupa, em Gonçalo Mendes, é o seu temperamento passivo e o seu pendor para um ócio algo abúlico, afectado por um Romantismo serôdio e retórico: se o Romantismo de W. Meister é sincero, «o do Gonçalo, pelo contrário, não o é: não passa de um gesto de imitação literária. É Gonçalo Mendes um «bom rapaz», mas descentrado: nem sombra apresenta de autonomia do espírito; inoculou-lhe um amigo aquela retórica, e ele aceitou» $\left({ }^{24}\right)$. A partir daqui, Sérgio descreve aquelas que, do seu ponto de vista, são as linhas de força que regem o protagonista d'A Ilustre Casa de Rami-

$\left({ }^{23}\right)$ Ensaios, tomo III, pp. 133-134.

(M) Ensaios, tomo IV, p 180. 
res: a admiração acrítica pelo passado medieval, a evasão africana como manifestação do seu pendor romântico e centrífugo, o cariz inconsequente das soluções de auto-superação e regeneração procuradas por Gonçalo, a sua dimensão de figura que simbolicamente representa Portugal.

Nas dominantes apresentadas (e que no ensaio o são de forma um tanto desgarrada, porque envolvidas numa aproximação relacionadora e contrastiva com outras personagens literárias) encontram-se não só pistas de leitura importantes para a valorização crítica d 'A Ilustre Casa de Ramires, mas também limitações e lacunas decorrentes de um processo interpretativo algo parcelar e descontextualizado. Com efeito, parece poder inferir-se de certos gestos e reacções de Gonçalo uma atitude de contemplação admirativa pelo passado medieval, concretamente pelo que a família Ramires ajudou a configurar; há-de notar-se, no entanto, que o fidalgo da Torre reage também, em termos inequivocamente críticos, a certos aspectos desse passado: à sua truculência, a alguma brutalidade e agressividade vingativa, etc. Estamos a pensar concretamente na superação da vingança, por parte de Gonçalo, quando este impede João Gouveia de proceder contra o valentão de Nacejas:

- Pelo amor de Deus, amigo Godinho! Não quero, e não quero... Explique bem ao sr. João Gouveia. Detesto vinganças. Não estão nos meus hábitos, nem nos hábitos da minha família. Nunca houve um Ramires que se vingasse... Quero dizer, sim, houve, mas... Enfim explique bem ao sr. João Gouveia. De resto eu logo o encontro, na Assembleia... Bem basta ao homem ficar desfeado. Não consinto que o apoquentem mais!... Detesto ferocidades (").

$\mathrm{O}$ facto de se eliminar a vingança significa sobretudo, do nosso ponto de vista, que o cenário medieval representado na «Torre de D. Ramires» não constitui um domínio de pura admiração passiva e nostálgica. Ele inspira a dinâmica evolutiva vivida pelo protagonista, dinâmica essa que leva Gonçalo, decerto, a observar no passado exemplos a cultivar (a lealdade, o vigor anímico, etc.), mas também a superar o que de negativo ou desajustado ao presente lhe aparecia nesse passado.

$\mathbf{C}^{25}$ ) Eça de Queirós, A Ilustre Casa de Ramires, $2^{\text {a }}$ ed., Lisboa, Livros do Brasil, s/d., p. 327. Cf. o nosso Estatuto e perspectivas do narrador na -ficção de Eça de Queirós, 2. ${ }^{a}$ ed., Coimbra, Almedina, 1980, pp. 272 ss., onde analisámos este episódio no contexto das relações entre dois niveis diegéticos: a história contada na novela «Torre de D. Ramires» e a vivida por Gonçalo. 
É, pois, em função de uma leitura global do romance que há que interpretar o perfil da personagem e não apenas tendo em conta aspectos fragmentários e desenquadrados do seu devir. Certamente que este devir seria mais evidente se no romance se manifestasse um entrecho com avanços bem marcados e com um desenlace irrevogável; tal entrecho não existe, no entanto, podendo A Ilustre Casa de Ramires ser, sem esforço, situada na classe dos romances de acção aberta, de acordo, aliás, com a superação, por parte de Eça, de processos de análise determinista e naturalista. E é justamente por isso que não nos parece correcto interpretar a ida a África em termos conclusivos ou irreversíveis, como entende Sérgio $\left({ }^{26}\right)$, mas antes como uma das etapas da já citada dinâmica evolutiva que, no entanto, fica em aberto. De facto, Gonçalo não vai apenas a África: ele regressa também. Mais: não se chega a saber se esse regresso é definitivo ou provisório, porque decidi-lo seria retirar ao romance as virtualidades de intervenção sociocultural e de estímulo reflexivo que Eça, afinal, lhe atribuiu.

Isto quer dizer, por outras palavras, que à sua configuração de narrativa aberta, A Ilustre Casa de Ramires junta, no último capítulo (que é preciso 1er como elemento integrado também na orgânica da história, depois da ida para Africa) não só diversas sugestões quanto ao futuro de Gonçalo, mas também quanto ao seu significado. E se falamos apenas em sugestões, é porque os elementos aduzidos são-no em termos específicos que há que ter em conta, exactamente porque à abertura estrutural do romance junta-se a abertura semântica, ou seja, virtualidades interp relativas que o escritor não resolve $\left({ }^{27}\right),{ }^{*}$ vale a pena, para o atestarmos, recordar breve-

É o que se deduz do trecho em que Sérgio observa que «fazê-lo [a Gonçalo] abalar para além dos mares redunda em insistirmos precisamente num dos erros mais graves da nossa gente: o de pretender um Império colonial pujante com uma vida europeia das mais miseráveis» (Ensaios, tomo IV, p. 185; cf. também pp. 184 e 187).

$\left({ }^{27}\right)$ Não se esqueça também que a esta suspensão vem juntar -se uma outra: a que decorre do facto de o escritor não ter corrigido, por completo, as provas tipográficas da edição do romance em livro; e este facto não é despiciendo, porque, como se sabe, Eça emendava, por vezes consideravelmente, o texto das primeiras provas. Isto para já não falarmos de um outro tipo de alterações, neste momento irrelevantes: as sofridas pelo texto da primeira versão d'A Ilustre Casa de Ramires, publicada na Revista Moderna, entre 1897 e 1899 (cf. Carmela Magnata Nuzzi, Análise comparativa de duas versões de A Ilustre Casa de Ramires de Eça de Queirós, Porto, Lello, 1976, pp. 32-37). 
mente o processo de representação instaurado no capítulo final d'A Ilustre Casa de Ramires.

7. Nele, elabora-se uma retrospectiva que, de forma abreviada, compensa os quatro anos entretanto decorridos, depois da partida de Gonçalo, retrospectiva que, entretanto, visa sobretudo os incidentes da vida de Gracinha, que ê quem rememora esse tempo. Quer dizer: é a memória de uma personagem, a sua capacidade de retenção, a sua visão subjectiva das coisas, a parcialidade dos seus juízos, que mediatizam a representação da história, deixando na obscuridade quase total o destino de Gonçalo em África: deste sabe-se apenas que ia «mandando raras cartas, mas alegres, e com um entusiasmo de fundador de Império» $\left({ }^{28}\right)$.

Este critério parcelar e parcial de representação não se esgota, no entanto, com a evocação de Gracinha. Também as notícias do regresso de Gonçalo são filtradas pelo testemunho de uma personagem: pela tagarelice e pela vocação casamenteira de D. Maria Mendonça, que se demora sobretudo nos incidentes anedóticos da chegada. A propósito do Gonçalo-colono, é referida apenas, em termos vagos, a prosperidade da exploração, acrescentando-se que «o primo Gonçalo declara que já não vende o prazo nem por oitenta contos. Para felicidade completa, até achou um excelente administrador. Eu todavia duvido que ele volte para a África. Tenho agora cá a minha linda ideia sobre o futuro do primo Gonçalo» $\left({ }^{29}\right)$. Significa isto que, em definitivo, não se sabe se o fidalgo volta ou não para África (uma personagem supõe que ele nã̃o o fará), como se ignora se Gonçalo casará ou não; de facto, a «linda ideia» de D. Maria Mendonça não é mais do que outra conjectura: a de que se está preparando (e não por iniciativa do interessado) o casamento de Gonçalo com a Rosinha do Rio-Manso.

Ora isto é importante. De facto, regressar a África ou confiar a administração a outrem constituem soluções muito diversas para a empresa africana iniciada por Gonçalo, pois a primeira representa o empenhamento pessoal e decidido, e a segundo o «comodismo» da administração distanciada e por interposta pessoa; por outro lado, casar ou não, significa continuar a raça dos Ramires ou consentir na sua extinção; e no primeiro caso, o casamento constituiria, por sua vez, uma alternativa à solução africana (quer dizer, ao impulso de regeneração económica livremente assumido), através do «dote

${ }^{(28)}$ A Ilustre Casa de Ramires, p. 348.

(*u) A Ilustre Casa de Ramires, p. 355. 
tremendo» da noiva («Falam em quinhentos contos», esclarece D. Maria Mendonça $\left({ }^{30}\right)$ ), mesmo à custa de uma transigência em relação à «pureza de sangue». Mas «enfím, comc se diz em heráldica, - 'o rei faz a pastora rainha'», palavras ainda de D. Maria Mendonça, na carta que temos vindo a citar.

O significado de que tudo isto pode revestir-se, sobretudo se entendermos o romance, como nos parece necessário, enquanto prática cultural relacionada com o seu melindroso envolvimento histórico e social (sequelas do Ultimato e do 31 de Janeiro, crise do regime monárquico, decadência económico-financeira, etc., etc.), tal significado, dizíamos, tem que ver com um último aspecto do protagonista da história: a sua interpretação como símbolo de Portugal, que a Sérgio aparece como um dado adquirido $\left.{ }^{31}\right)$. Ora, novamente neste caso, a interpretação parece-nos discutível (o que não quer dizer que seja descabida) por força dos termos ambíguos em que o problema é equacionado.

Com efeito, o símbolo-Gonçalo configura-se como tal novamente pela intervenção de uma personagem, neste caso João Gouveia, que, discorrendo sobre as qualidades e os defeitos do Fidalgo da Torre, sugere aos amigos (e em certa medida apoiado em observações por eles mesmos feitas) a semelhança com Portugal $\left({ }^{32}\right)$. Mas mesmo admitindo-se que Padre Soeiro, Titó e Videirinha aceitam tacitamente uma tal semelhança, isso não quer dizer que ela deva ser entendida como directriz interpretativa avalizada pelo escritor; de novo, trata-se de uma voz particular e não demiúrgica, com todas as limitações e

(30) A Ilustre Casa de Ramires, p. 355.

(31) Atente-se nas seguintes passagens do ensaio: «Não é [o] Ramires um indivíduo qualquer: deram-no-lo como um símbolo de Portugal»; «É isto um defeito, se não digo asneira: e defeito (ao que me parece) quer consideremos a individualidade Gonçalo, quer o povo português de que é ele [o] símbolo» (Ensaios, tomo IV, pp. 185 e 187).

${ }^{32}$ Cf. A Ilustre Casa de Ramires, pp. 361-362. Comentando o episódio final d'A Ilustre Casa de Ramires, António Cirurgião observou justamente que «quando se analisa a ideia central de uma obra de arte, a primeira atitude do crítico deve ser verificar se se trata apenas da opinião de determinada personagem ou do significado último da obra, na sua totalidade»; e embora não conclua se João Gouveia se pronuncia por si só ou como porta-voz desse «significado último», Cirurgião nota que, se a personagem fala em nome pessoal, «a sua opinião é bastante discutível e duvidosa, por quanto [sic] Gouveia, através do romance, desempenha um papel que de maneira nenhuma prima pela nobreza de carácter» ( $\mathrm{A}$. Cirurgião « $\mathrm{A}$ estrutura de "A ilustre casa de Ramires» de Eça de Queiroz», Ocidente, vol. LXXVII, n. ${ }^{\circ}$ 337, Lisboa, 1969, p. 144. 
parcialidade judicativa (não é verdade que João Gouveia discorda até da opção africanista de Gonçalo?) que esse estatuto implica - bem ao contrário do que se encontra consignado no final d'0 Crime do Padre Amaro, quando o discurso de um narrador por assim dizer inequivocamente peremptório e conclusivo, nota a decadência do cenário representado (o Largo do Loreto), em vivo contraste com a imagem do Épico «cercado dos cronistas e dos poetas heroicos da antiga pátria pátria para sempre passada, memória quase perdida!» $\left({ }^{33}\right)$.

Com A Ilustre Casa de Ramires, a ficção queirosiana encontra-se num momento ideológico e estético-literário adverso a postulações impositivas, no que toca aos fundamentais vectores semânticos a deduzir da obra literária. Em vez disso, Eça parece perfilhar a fluidez das formulações ambíguas, o carácter difuso das propostas interpretativas (e não mais do que isso) veiculadas pela fícção; e fá-lo, quiçá porque assim convoca a cooperação do destinatário chamado a "completar», com a sua leitura, uma obra literária que, talvez mais do que qualquer outra, lançou as premissas (a evocação do passado, o contraste com o presente) para uma equacionação do destino futuro da Pátria. E esta não será já tarefa do romancista, mas dos que souberem entender a sua obra como estímulo à reflexão colectiva, mais do que como prontuário de receitas definitivas.

Com o exposto não se põe propriamente em causa a legitimidade das interpretações colhidas por Sérgio ri A Ilustre Casa de Ramires e no seu protagonista. Mas importa matizar, em nossa opinião, o grau de convicção com que formulou essas interpretações; e isto porque elas não podem ignorar os modos de representação (as vozes das personagens, os seus pontos de vista, a instância da subjectividade, etc.) que condicionam os sentidos nucleares do romance. Modos de representação que, por isso mesmo, solicitam uma leitura atenta aos seus processos e marcas de inscrição no discurso que os articula e que, em função deles, assume um perfil específico.

8. Mas o ensaio capital consagrado por António Sérgio a Eça de Queirós é o que se encontra no tomo VI. Capital não só porque específica e longamente centrado sobre Eça, mas também por se nos revelar como amadurecida reflexão acerca de um escritor desde muito cedo colocado no eixo das preocupações culturais sergianas. Por outro lado, é ainda pelos

${ }^{(33}$ ) Eça de Queirós, O Crime do Padre Amaro, 6. ${ }^{\mathrm{a}}$ ed., Lisboa, Livros do Brasil, s/d., p. 500. 
problemas teórico-metodológicos que levantam que as «Notas sobre a imaginação....» se nos revelam extremamente fecundas, no sentido de avaliarmos o que no Sérgio queirosiano ainda hoje sobrevive, como importante contributo para a compreensão do autor d'Os Maias, e também o que nas suas leituras se manifesta precário' ou inconsistente, por força de limitações exactamente provenientes da citada área teórico-metodológica.

Digamos que aquilo que, em nossa opinião, permanece indiscutivelmente pertinente é a captação, por parte de Sérgio, do que ele chamou a «tese-cúpula». "O Tédio do Ócio: tal é, conjecturo eu, o fenómeno psicológico fundamental na obra romanesca queirosiana» $\left({ }^{34}\right)$, afectando diversas personagens (normalmente os protagonistas), n'0 Primo Bazilio e n'A Cidade e as Serras, $n O$ Mandarim, nA Ilustre Casa de Ramires, $\mathrm{n}^{9} A$ Relíquia e n'Os Maias, para vir a resolver-se, já no crepúsculo da produção literária de Eça, nas Lendas de Santos. Só aí se encontra «o não-ócio que nos salva, o redentor por excelência, - é a acção generosa; o perfeito antídoto para o tédio da vida, para o fastio das paixões, para a inércia do intelecto, - está no magnânimo trabalho para o bem do próximo, no amor espiritual, na actuação liberalíssima; por outras palavras: numa interpretação racionalista dos dizeres do Cristo: 'o que acha a sua alma perdê-la-á; e o que perde a sua alma por amor de mim, esse achá-la-á'» $\left.{ }^{35}\right)$.

Descrevendo e caracterizando esta Tese-das-teses, Sérgio pretende, por outro lado, compensar, no plano da reflexão ensaística, aquilo que em Eça seria uma limitação: a incapacidade para se aperceber da existência dessa Tese-das-teses, por força de uma sobrecarga de imaginação, em detrimento da fantasia ou inventiva relacionadora, quer dizer, «o poder de intuir desenvolvimentos psíquicos, que distingue os romancistas profundamente psicólogos, ou.... o dom de invenção de relações entendíveis (de verdadeiras ideias, ou Formas platónicas) que caracteriza a mentalidade dos criadores científicos, a dos verdadeiros filósofos»» $\left.{ }^{36}\right)$. Por outras palavras, isto significa que Sérgio vai à procura de um implícito que Eça teria ignorado; de facto, «se [ele] fosse uma mente do que chamei fantasia e houvesse visto profundamente os temas- descobriria que é isso que está no cerne daquilo que

$\left({ }^{34}\right)$ Ensaios, tomo VI, p. 65.

(35) Ensaios, tomo VI, pp. 114-115.

$\mathbf{C}^{36}$ ) Ensaios, tomo VI, p. 55. Por imaginação ou inventiva $f i$ guradora entende Sérgio, "a faculdade de criar e combinar imagens, coisa do domínio do sensível» (loc. cit.). 
lhe aparecia sob figuras várias na tela exteriorista do imaginar sensível» $\left({ }^{37}\right)$. Ora esta busca do impícito parecer-nos-ia inteiramente legítima (não escreveu Serge Doubrovsky que «la critique consistera à révéler ce qui se cache et à raccorder ce qui se donne à ce qui se dérobe, dans un effort pour dégager la totalité de Yexpression»? $\left.\left({ }^{38}\right)^{3}\right)$, se ela não tivesse justamente intuitos compensatórios, ou seja, se não fosse empreendida como correcção de uma deficiência que, em nossa opinião, não existe.

Vejamos: Sérgio reconhece que «o novelista .... não estava obrigado a congeminações morais»; mas, por outro lado, observa que «na obra de Queirós (artífice literário a que nenhum preleva) assiste-se de facto ao aflorar frequente de uma tese cristã contra a civilização mamónica, de um intuito justiceiro antiburguês: mas é só um aflorar; é um perpassar somente». E conclui: «O pregador moralista e o construtor do entrecho são pessoas distintas, sem liame entre si, no processo de realização dos seus romances; só nas lendas de santos a união se fez» $\left({ }^{39}\right)$. Ora parece poder inferir-se destas palavras que, na opinião de Sérgio, Eça teria cumprido com maior eficácia a sua missão de reformador dos costumes e das mentalidades se tivesse imprimido um cunho injuntivo à sua mensagem (não só literária, mas também de recorte moral), procurando atingir com maior nitidez e eficácia o seu destinatário. E para tal, excelentemente teriam servido personagens que de forma linear corporizassem as preocupações éticas do seu autor; lamentavelmente (do ponto de vista de Sérgio, note-se) «aquilo que se manifesta nas principais figuras - ainda depois da inflexão da vida, da meditação moral, - não passa nunca de ambição burguesa, de naturalismo estreme: dinheiro e poder - o poder imoralíssimo que do dinheiro vem» $\left({ }^{40}\right)$.

Acontece, todavia, que as personagens da ficção queirosiana (como geralmente acontece também nas obras de muitos outros romancistas...) não são santos: são burgueses e políticos, filhos-família e aristocratas em crise, diletantes e amanuenses. Santos, encontramo-los nos derradeiros textos de Eça (textos ainda assim precários, porque não publicados

\footnotetext{
$\left(\begin{array}{c}37 \\ 38\end{array}\right)$ Ensaios, tomo VI, p. 65.

(38) Serge Doubrovsky, Pourquoi la nouvelle critique, Paris, Denoël/Gonthier, 1966, p. 207.

(30) Ensaios, tomo VI, pp. 86 e 86-87.

(40) Ensaios, tomo VI, p. 90.
} 
por iniciativa do autor $\left({ }^{41}\right)$ ), nessas Lendas de Santos em que Sérgio encontra finalmente - e ainda assim de forma plena apenas no S. Cristóvão - o remédio para o Tédio do Ócio.

$O$ que com isto queremos significar é que, antes de tudo, pareceria inverosímil e incoerente, em função da economia interna das obras, encontrar em personagens como Teodorico Raposo ou Gonçalo Mendes Ramires a plena e redentora regeneração dos seus males morais. Por outras palavras, isto quer dizer que a mensagem que um romance nos faculta deduz-se também (íamos a dizer: deduz-se quase sempre) a partir das contradições, dos fracassos, dos conflitos íntimos, das derrotas, dos anseios e das frustrações vividas pelas figuras que o povoam; só uma literatura primariamente mo* ralizadora, edificante e idealista conceberia personagens que tivessem «na mente, a prudência de Salomão, e nos lábios, a eloquência de Santo Agostinho» — palavras do próprio Eça ao verberar precisamente essa literatura divorciada de uma realidade a que, nem nas suas obras pós-naturalistas, o escritor virou costas $\left({ }^{42}\right)$. Isto para deixarmos, por agora, de lado sinuosos processos de representação literária como a ironia ou a simbolização, a dialéctica dos pontos de vista ou a articulação polifónica de diversas instâncias subjectivas, da voz do narrador às das personagens $\left({ }^{43}\right)$.

$\left({ }^{41}\right)$ Note-se que a assinalada precaridade não tem que ver apenas com o acabamento propriamente formal do texto (sempre muito árduo e elaborado, no caso de Eça), mas também com a decisão de publicar o que se considera estar em condições de aparecer aos olhos do público.

$\left.{ }^{(42}\right)$ O fragmento citado pertence a um importante texto programático de Eça: «Idealismo e Realismo», Cartas inéditas de Fradique Mendes e mais páginas esquecidas, Porto, Lello, 1965, p. 181. Note-se que o facto de Eça ter deixado este texto inédito (à excepcão do trecho que serviu de prefácio à terceira versão d'O Crime do Padre Amaro) pode explicar-se sobretudo por motivos de conveniência: a sua sarcástica agressividade, tacitamente enderecada a Machado de Assis (cf. A. Machado da Rosa, Eça, discípulo de Machado?, Lisboa, Editorial Presença, s/d., pp. 209 ss. e 225 ss,), bem como o seu cunho fortemente doutrinário, no que à vinculação naturalista diz respeito, mas não certamente (as obras subsequentes de Eça atestam-no bem) quanto à predilecção por um posicionamento estético-literário de carácter genericamente realista e crítico.

${ }^{43}$ ) A história literária d'O Conde de Abranhos é muito curiosa a este propósito: escrita de um jacto, a obra é deixada na gaveta pelo autor, talvez porque (entre outras razões) a estratégia de representação perfilhada - a ironia, activada a partir do relato de um narrador caricatamente imbecil - colidia com aquele mínimo de clareza crítica que, na época, era solicitada pelo programa naturalista; mas o que é facto é que, já então, procedimentos de intenção crítica não lineares, ensaiados pelo escritor, tinham passado, como se vê, da 


\section{Antonio Sérgio}

Até certo ponto, não deixa de ser estranho que António Sérgio sugira a necessidade de uma transparência semântica inequívoca, como se desconhecesse que justamente os caminhos da representação literária estão longe de ser rectilíneos e isentos de desvios - até por força de interdições éticas ou de condicionamentos socioculturais que não cabe aqui aprofundar. De facto, ainda que de forma algo intuitiva, Sérgio parece consciente da peculiar configuração assumida pela obra literária e atento as consequências pragmáticas que daí advêm; em determinado momento do seu ensaio e a propósito de um episódio, declara que «qualquer descrição é um erro artístico sempre que se não insira de maneira plausível nos interesses psicológicos das personagens, ou nas necessidades e objectivos da sua acção». E logo na página seguinte, nota que $O$ Primo Bazilio, «pelo forte predomínio que nele cabe ao entrecho, tende para o romance de concentração dramática, no género de $O$ Crime do Padre Amaro; e pelo relevo das personagens inúteis (inúteis no sentido de não interferirem na acção) o Basílio propende para o outro tipo, que atingiu nos Maias o seu modelo: o de friso de personagens, o de galeria de quadros» $\left({ }^{44}\right)$.

Não está agora em causa avaliar a justeza das observações de Sérgio que, de resto, nos parecem inteiramente pertinentes. $\mathrm{O}$ que nos interessa é sublinhar que o autor dos $E m$ saios atenta na particular estruturação interna da obra de ficção, na interdependência e equilíbrio dos seus componentes, na tendência para a constituição de géneros de romance (melhor: subgéneros), como que proto-códigos subjacentes a manifestações concretas como O Crime do Padre Amaro ou Os Maias. Mas Sérgio, vai mais longe: interessam-lhe também os problemas da representação narrativa, numa acepção estrita da expressão, em sintonia com a alegada propensão queirosiana para incrementar a já citada «faculdade de criar e combinar imagens, coisa do domínio do sensível». Daí a afirmação de que «em Eça de Queirós, essa própria mentalidade exteriorista e imagética (e as modalidades da fala são exteriores) o levava a atribuir um excessivo alcance ao colorido do estilo e à reprodução do visual, como factores do talento de criar romances»; e mais adiante: «Alucinatórios ou não, são sempre espectáculos e representações no espaço que de-

fase embrionária (na sua Bibliografia queirociana, o Prof. Guerra da Cal situa a composição d'O Conde de Abranhos em finais de 1878, princípios de 1879 ; cf. $o b$. cit., tomo I, p. 384).

$\left.C^{4}\right)$ Ensaios, tomo VI, pp. 59-60. 
sencadeiam nas figuras dos seus romances as ideias culminantes e decisivas. Obedecem a impulsos que se criam nelas por impressões sensíveis e ocasionais, pelo acaso de disposições meramente exteriores, de natureza física» $\left({ }^{45}\right)$.

O que daqui se infere é que António Sérgio não se alheia da peculiaridade compositiva e técnico-narrativa que preside ao romance queirosiano, na sua condição de modelização artística dos problemas sociais, culturais e ideológicos que atravessam a sua ficção. Só que não deixa de perpassar nos comentários sergianos uma entoação pejorativa suscitada pela verificação de que «nos heróis do Eça as ideias culminantes nunca são espontâneas, nunca vêm de dentro, nunca surdem nas almas por urdidura própria, pelas ligações internas de emoção e de ideia. É um aspecto da passividade que os caracteriza a todos» $\left({ }^{46}\right)$; assim se tende a confundir dois planos de análise distintos: o que se relaciona com a configuração psicológica das personagens, marcadas pela vivência do Tédio do Ôcio, e o que tem que ver com as consequências arrastadas pela adopção de critérios específicos de representação literária, capazes de distorcerem a transparência dos fenómenos e eventos relatados, assim se afectando a eficácia da reforma moralizadora que Sérgio descortina, enquanto in-, tenção, no Eça alegadamente moralista e revolucionário. É esta tendência para confundir planos de análise distintos que de seguida nos interessa considerar, tendo em conta as considerações provocadas por dois dos principais romances queirosianos.

9. $\quad \mathrm{Na}$ análise sergiana d'O Primo Bazilio (e, com mais demora, da sua protagonista), a citada confusão de planos de análise decorre do tipo de aproximação levada a cabo pelo ensaísta, entre dois textos de natureza distinta: o artigo d'As ${ }^{(*)}$

(*) Ensaios, tomo VI, respectivamente pp. 58 e 85 . É curioso notar como as palavras da segunda citação se ajustam, com uma perfeição notável, a diversos episódios d'Os Maias; lembremos, a título de exemplo, o momento em que Carlos se encontra em Sintra: depois de ver frustrado o seu encontro com Maria Eduarda, é a imagem desta, envolvida num halo de conotações divinizantes - e também, de forma subtil e algo insidiosa, marcada por premonições trágicas - é essa imagem, dizíamos, que é sugerida ao protagonista, a partir da contemplação do espectacular cenário de Sintra (cf. Os Maias, Lisboa, Livros do Brasil, s/d., pp. 245-246 e o comentário que este trecho nos mereceu no nosso Estatuto e perspectivas do narrador na ficção de Eça de Queirós, ed. cit., pp. 152-153).

$\left.{ }^{46}\right)$ Ensaios, tomo VI, p. 85. 
Farpas sobre «O problema do adultério» e o romance em questão. Trata-se, antes de mais, de evidenciar a falta de representatividade social da acção d 'O Primo Bazilio: "Como estudo sociológico, o enredo é falso, porque lhe falta ser típico: e, não sendo típico, nada nos demonstra quanto à sociedade em geral. Sim: digo que o adultério não era caso típico na pequena burguesia do Portugal da época, isto é, na classe social a que pertencia a Luísa, e escudo-me num depoimento do próprio Eça, no segundo volume da Campanha Alegre, artigo de Outubro de $72 »\left({ }^{47}\right)$. E, de seguida, Sérgio transcreve a longa passagem do texto em causa, na qual șe afirma «que as mulheres ocupadas são as mais virtuosas. E isto evidente na pequena burguesia, no mundo proletário, nas classes agrícolas» $\left({ }^{48}\right)$.

Atentemos, antes de mais, na questão do típico. Se o texto d'As Farpas fosse suficiente (veremos que o não é) para atestar a falta de representatividade social da intriga d'O Primo Bazilio, haveria que explicar o que levou Eça, logo depois da publicação do romance, a escrever, numa importante carta a Teófilo Braga, o seguinte: «O Primo Basílio apresenta, sobretudo, um pequeno quadro doméstico, extremamente familiar a quem conhece bem a burguesia de Lisboa: a senhora sentimental, mal-educada, nem espiritual (porque, Cristianismo, já o não tem; sanção moral da justiça, não sabe o que isso é) arrasada de romance, lírica, sobreexcitada no temperamento pela ociosidade e pelo mesmo fim do casamento peninsular, que é ordinariamente a luxúria, nervosa pela falta de exercício e disciplina moral, etc., etc. - enfim, a burguesinha da Baixa»; e depois de se referir aos comparsas de Luiza conclui: «Um grupo social, em Lisboa, compõe-se, com pequenas modificações, destes elementos dominantes. Eu conheço vinte grupos assim formados» $\left({ }^{49}\right)$. Por outras palavras, é o próprio Eça quem reclama esse típico que Sérgio contesta.

Pode certamente objectar-se que a carta a Teófilo Braga enferma de uma espécie de «excesso de zelo», ou seja, de um desejo de evidenciar junto do destinatário (que tinha então sobre Eça um certo ascendente ideológico, patenteado na própria carta) o cumprimento escrupuloso de um programa de reforma moral e social; mas também pode duvidar-se da pertinência da análise levada a cabo pelo texto d'As Farpas. 51-52.

$\left.C^{l}\right)$ Ensaios, tomo VI, p. 70.

(48) Loc. cit., p. 71.

$\left({ }^{49}\right)$ Eça de Queirós, Correspondência, Porto, Lello, 1967, pp. 
Repare-se: Eça observa que «Lisboa é uma terra de mulheres virtuosas» e logo depois acrescenta: «Podem rir-se os incrédulos da cidade, les rieurs de la ville, como dizia Talemand des Réaux» $\left({ }^{50}\right)$. O que significa que não se tratava de uma afirmação pacífica e que, como tal, havia que apoiá-la numa fundamentação convincente.

$\mathrm{E}$ isso que Eça procura fazer: «A verdade é essa, e a razão é que Lisboa é uma terra pobre: a maior parte das famílias são de empregados públicos, e portanto as mulheres, sem criadas, sem aias, e sem carruagens, têm, de manhã à noite, o rude trabalho de uma casa a dirigir; têm de se vestir, de lavar os filhos, de alinhavar vestidos, de tomar róis, de fazer as suas compras; e fica-lhes um dia cheio e trabalhado» $\left(^{51}\right)$. Isto significa, pois, que tais mulheres não enfermam do Tédio do Ócio que afecta Luiza, não incorrendo, por isso, nos riscos do adultério. Ora, o que é preciso saber é se a protagonista d'O Primo BazUio se ajusta ao perfil esboçado por Eça n'As Farpas e invocado por Sérgio (deliberadamente temo-nos servido das suas citações para melhor acompanharmos o seu raciocínio); conhecendo o romance, parece-nos que não, coisa que, aliás, o próprio Sérgio acaba por reçonhecer, quando declara que Luiza "exorbita das condições normais enumeradas no artigo da Campanha Alegre: não tem filhos, nem pai, nem mãe, nem sogro, nem sogra, nem tios, nem irmãos, nem sobrinhos; coisa alguma a prende, nada lhe impõe deveres» $\left({ }^{52}\right)$.

Em conclusão, tudo isto quer dizer que não é evidente que O Primo BazUio corresponda, no plano da ficção, aos problemas levantados na «farpa» sobre «O problema do adultério» (talvez, apesar de tudo, ande mais perto dos abordados no artigo «As meninas da geração nova em Lisboa e a educação contemporânea») ou que, pelo menos, o romance represente o mesmo universo social visado pelo artigo. Mas além disso, outro dado pode apontar no sentido do desajustamento: o facto de haver um lapso de tempo não despiciendo entre o artigo e o romance (aquele data de 1872, o romance é publicado em 1878 e redigido entre 1876 e 1877), permitindo ao escritor rever e consolidar o seu conhecimento da sociedade portuguesa, o que, de resto, nele não era inédito; basta lembrarmos o depoimento acerca da elaboração e amadure-

$\left(\begin{array}{l}\mathrm{M} \\ )\end{array}\right)$ Loc. cit.y p. $\mathbf{7 1}$.

(51) Loc. cit.y p. 71 .

(52) Ensaios, tomo VI, p. 74. Também por isso parece-nos discutível integrar Luiza no estatuto da pequena burguesia, como sugere Sérgio um pouco antes (cf. loc. cit. ${ }_{f}$ p. 72). 
cimento de uma outra obra coeva: «Quando publiquei pela primeira vez O Crime do Padre Amaro, eu tinha um conhecimento incompleto da província portuguesa, da vida devota, dos motivos e dos modos eclesiásticos. Depois, por uma frequência demorada e metódica, tendo talvez observado melhor, eu refiz simplesmeente o meu livro sobre estas bases de análise» $\left({ }^{53}\right)$.

A tudo isto poderíamos ainda acrescentar um outro argumento contra a aproximação As Farpas/O Primo Bazilio, não por essa aproximação em si, mas pelos termos lineares em que é levada a cabo por Sérgio: referimo-nos ao facto de se tratar de textos de natureza diversa (o primeiro praticamente no domínio do jornalismo panfletário, o segundo no da fícção literária), o que naturalmente prejudica a tentativa de se ver no romance um simples prolongamento da análise concretizada $n A s$ Farpas; por isso, muito mais pertinente e consequente parece-nos ser o esforço sergiano para estabelecer relações entre O Primo Bazilio e Madame Bovary de Flaubert. E isto por duas razões: antes de mais porque essas relações têm em conta elementos de natureza afim (o romance, o realismo, a crítica de costumes), em segundo lugar porque se não procura trilhar o percurso mais fácil, que consistiria em sobrepor as protagonistas de um e outro e ver em Luiza uma Emma à portuguesa $\left({ }^{51}\right)$; em vez disso e justamente porque se preocupa mais com a esfera do psicológico do que com a do social, António Sérgio revela-nos uma Leopoldina que, essa sim, corresponde ao perfil da personagem bovarista: «O ímpeto para a aventura é nela inato; a iniciativa vem dela, constantemente, ao contrário da Luísa, que é só levada» $\left({ }^{55}\right)$.

10. As limitações de ordem metodológica que encontramos na análise sergiana d'Os Maias (e de novo predominantemente do seu protagonista, de forma algo isolada, o que provoca riscos de apreciação por descontextualização) são diversos dos que encontrámos na leitura d'O Primo Bazilio. De um modo geral, eles derivam da subalternização dos critérios de representação que, numa obra literária e não num texto folhetinesco ou jornalístico, retiram aos problemas equa-

$\left({ }^{53}\right)$ «Idealismo e Realismo», loc. cit., p. 167.

() Num breve artigo em que nos debruçámos sobre as «Leituras de Flaubert em Eça», referimo-nos precisamente aos termos em que a crítica queirosiana se tem interessado pelas conexões entre os dois romancistas (cf. Construção da leitura, Coimbra, I.N.I.C., 1982, pp. 131-136).

$\left({ }^{55}\right)$ Ensaios, tomo VI, p. 76. 
cionados a transparência que conviria a uma leitura de intenção unicamente ideológico-social, mas que uma leitura propriamente crítica não pode exigir.

Um dos temas privilegiados na reflexão sergiana é o da educação, tendo em conta sobretudo as suas consequências no presente adulto do protagonista. Ora as apreciações formuladas por Sérgio parecem-nos, pelo menos, arrojadas, tendo em conta o que o romance nos relata: afirma o ensaísta que «àquilo 'educação' nunca poderá chamar-se»; que «o tratamento que se deu ao Carlinhos foi em tudo exactamente o de maior eficácia para lhe agravar os defeitos naturais inatos»; que «o que se the deu para preceptor foi um rematado bruto, cujo ideal pedagógico se resumia nisto: forrrça, forrrça, músculo, músculo....» $\left.{ }^{56}\right)$.

Se António Sérgio estivesse a falar do jovem Amaro Vieira, diríamos que, a propósito deste, não faltam, de facto, informações que permitem fazer uma ideia extremamente pormenorizada dos seus condicionamentos educacionais: quem foram os seus educadores, que disciplinas lhe foram ministradas, que doutrina se lhe ensinou no seminário, que ambiente o rodeou, etc. E isto porque a representação narrativa que mediatiza a descrição do processo educativo de Amaro depende do posicionamento transcendente de um narrador que domina a história $\left({ }^{57}\right)$. Ora não é assim que acontece n'05 Maias, pelo menos em relação a Carlos da Maia.

Noutro local, tivemos já oportunidade de distinguir, no romance em causa, dois tipos de representação da educação: o que se ocupa de Pedro da Maia (cap. I) e o que incide sobre Carlos da Maia (cap. Ill) $\left({ }^{58}\right)$. O primeiro é tributário de uma estratégia de perspectivações ainda de filiação naturalista, afim da que mencionámos a propósito de Amaro Vieira, constituindo uma sobrevivência de procedimentos técnico-literários então em via de superação; o segundo corresponde ao tipo de perspectivação longamente utilizada n'Os Maias, ou seja, aquela em que a diegese é filtrada pela visão (e também pelas peculiares reacções subjectivas) de uma personagem nela integrada.

No capítulo III, é a visão do procurador Vilaça que condiciona a representação da história, à excepção de breves e esporádicos momentos (mas um esporádico ainda assim im-

(") Ensaios, tomo VI, p. 98.

(5T) Cf. o nosso Estatuto e perspectivas do narrador na ficção de Eça de Queirós, ed. cit., pp. 59-60.

${ }_{\left({ }^{58}\right)}$ Cf. a nossa Introdução à leitura d'Os Maias, 4. ${ }^{\text {a ed., Coim- }}$ bra, Almedina, 1982, pp. 35-37 e 40-43. 
portante, como veremos). Repare-se: uma personagem (com os seus gostos particulares, a sua configuração ideológica própria, etc.) observa, aproximadamente durante um dia, alguns gestos, comportamentos e reacções de uma criança. Pergunta-se: é possível, a partir daqui, extrair ilações peremptórias e definitivas acerca do teor do programa educativo a que Carlos se submete? Pensamos que não. Daí que nos pareçam desajustadas e sobretudo desligadas do processo de representação narrativa, observações com esta: «Uma criança em baloiço pode ser bela à vista, sim (e foi a evoladura do espectáculo o que seduziu o Eça); mérito pedagógico, todavia, não vejo aí algum» $\left.{ }^{59}\right)$. Recorde-se, porque isso é importante, o fragmento do capítulo III a que Sérgio se refere:

Os três homens sentaram-se à mesa do café. Defronte do terraço, o Brown, de boné escocês posto ao lado e grande cachimbo na boca, puxava ao alto a barra do trapézio para Carlos se balouçar. Então o bom Vilaça pediu para voltar as costas. Não gostava de ver ginásticas; bem sabia que não havia perigo; mas mesmo nos cavalinhos, as cabriolas, os arcos atordoavam-no; saía sempre com 0 estômago embrulhado...

- E parece-me imprudente, sobre o jantar...

- Qual! é só balouçar-se... Olhe para aquilo! vena.

Mas Vilaça não se moveu, com a face sobre a chá-

O abade, esse, admirava, de lábios entreabertos, e o pires cheio de café esquecido na mão.

lhe faz mal, homem!

- Olhe para aquilo, Vilaça - repetiu Afonso. - Não

$O$ bom Vilaça voltou-se, com esforço. O pequeno, muito alto no ar, com as pernas retesadas contra a barra do trapézio, as mãos às cordas, descia sobre o terraço, cavando o espaço largamente, com os cabelos ao vento; depois elevava-se, serenamente, crescendo em pleno sol; todo ele sorria; a sua blusa, os calções enfunavam-se à aragem; e via-se passar, fugir, o brilho dos seus olhos muito negros e muito abertos $\left({ }^{60}\right)$.

São sobretudo dois movimentos que aqui se encontram representados: o da criança que se balouça e o de Vilaça cuja visão condiciona a quantidade (e a qualidade) das informações facultadas. Numa primeira fase, porque o procurador «pediu para voltar as costas», Carlos desaparece da cena do discurso; num segundo momento, «o bom Vilaça voltou-se, com esforço». E só então se descreve aquilo a que Sérgio chamou «a evoladura do espectáculo» que impressiona não

$\left(^{59}\right)$ Ensaios, tomo VI, p. 98.

(60) Eça de Queirós, Os Maias, pp. 65-66. 
propriamente o escritor Eça - a menos que se confunda o real (o escritor) com a ficção, isto é, a personagem que vê-, mas sim o estupefacto Vilaça.

Não está, pois, em causa a qualidade de uma educação (já vimos que se não dispõe de informações suficientes para dela se fazer uma ideia cabal), mas antes a sua diferença, a partir das informações filtradas pela óptica de Vilaça. E essa diferença carece, para se afirmar, de pontos de referência: a surpresa de Vilaça, português antigo, conservador, mas momentaneamente impressionável pelo vigor e vivacidade do jovem Carlos, e a presença contrastiva de Eusebiozinho. Ora nem o procurador nem o Silveirinha suscitam a atenção de Sérgio.

O facto, porém, é que, neste episódio do capítulo III, Eusebiozinho é uma personagem importante; ignorá-lo corresponde, pois, a analisar o momento-infância de Carlos, sem se considerar devidamente o envolvimento contextuai que enquadra esse momento. E de tal modo é significativa a presença de Eusebiozinho em Santa Olávia que uma ocorrência de omnisciência narrativa, no capítulo III (rompendo, portanto, de forma esporádica, com o predomínio da visão de Vilaça) é inspirada precisamente pela figura e pelo perfil psicológico do Silveirinha $\left({ }^{61}\right)$. Quer dizer: a sisudez melancólica de Eusebiozinho, a bafienta clausura em que é educado, a carência de exercício, o amolecimento do Ultra-Romantismo (logo depois a criança evidencia as suas «prendas» recitando «A Lua de Londres»), tudo isso configura um retrato em flagrante contraste com o que de Carlos nos é revelado.

Não iremos, naturalmente, ao ponto de insinuar que, rejeitando o que supõe (não mais do que isso) ser o programa educativo de Carlos, António Sérgio optaria pelo de Eusebiozinho. O facto, porém, é que ao ensaísta escapou o que existe, pelo menos, de intuito de ruptura cultural, por parte de Afonso da Maia, ao avalizar procedimentos educativos que, embora revelados de forma parcial, parecem destoar dos modelos consagrados na sociedade portuguesa da época.

Mas admitamos que esta relação de contraste entre Carlos e Eusebiozinho não é suficiente para se ver na educação do primeiro uma tentativa de superação da que orienta o segundo. Mesmo assim, subsistiriam as limitaçồes impostas pela representação a partir da óptica de Vilaça, limitações que, podendo ser lidas como signo de uma inflexão ideológica anti-naturalista, em certa medida desautorizam a estratégia cau-

(") Cf. Os Maias, pp. 68-69. 
salista de análise levada a cabo por Sérgio, quando afirma que «a educação acentuou o que é temperamental no Carlos, e os seus gestos finais são expressão da inércia (digo inércia mental, não inércia fisiológica)» $\left({ }^{62}\right)$; trata-se, com estas palavras, de demonstrar que a reacção («meramente físiológica» e não moral) de Carlos ao incesto é motivada justamente pela educação.

Não procuraremos, no presente contexto, saber se essa reacção é reprovável ou apenas verosímil (Sérgio não considera, por exemplo, a questão de saber como agem, no indivíduo e ao nível do super ego, as interdições morais que bloqueiam a prática do incesto); em vez disso, interessa-nos contestar o raciocínio causalista perfilhado pelo ensaísta. É que aceitá-lo corresponde a adoptar uma estratégia de análise desajustada da problemática ideológica e dos procedimentos técnico-literários que regem o tratamento do protagonista: este não é sujeito a uma caracterização de tipo determinista e de representação omnisciente que autorize a ler nas suas reacções e gestos de personagem adulta o desabrochar de embriões educacionais e temperamentais radicados na infância. Indo um pouco mais longe e atentando (como o faz João da Ega, no capítulo XVI $\left({ }^{63}\right)$ ) no que há de tragicamente inesperado e catastrófico no incesto, poderíamos dizer, com Jacinto do Prado Coelho, que, «se soubermos 1er Os Maias, Carlos não fraquejou por causa da educação recebida, mas apesar da educação recebida» $\left({ }^{64}\right)$.

Alargando o problema ao seu contexto histórico-literário e à evolução ideológica do escritor (o que Sérgio não faz), verifica-se que dificilmente se poderia atribuir à educação de Carlos o peso e as funestas responsabilidades que o autor dos Ensaios descortina. De facto, o Eça que escreve Os Maias é sobretudo um escritor em transformação e o seu romance uma obra ecléctica, traduzindo de forma talentosa essa transformação; significa isto que é justamente ao nível da temática da educação, enquanto condicionamento do devir das personagens, que com alguma segurança pode observar-se a supe-

$\left({ }^{62}\right)$ Ensaios, tomo VI, p. 103.

C $\left.^{63}\right)$ Cf. Os Maias, p. 621.

$\left({ }^{64}\right)$ J. do Prado Coelho, «Para a compreensão d'Os Maias como um todo orgânico», in Ao Contrário de Penélope, Amadora, Bertrand, 1976, p. 187. Curiosamente, no ensaio consagrado à componente social da ficção queirosiana, Sérgio parece ainda aceitar este ponto de vista, quando observa que "Carlos, com os melhores dotes naturais, um avô modelo, e a mais perfeita das educaçóes, cai, como um dos piores, na vadiagem e no incesto» (Ensaios, tomo III, p. 133). 
ração do código naturalista, inclusivamente comparando diversos aspectos da economia interna do romance - um romance que, não o esqueçamos, demorou longos anos a ser escrito, reflectindo por isso, em si mesmo, o processo evolutivo a que nos referimos. Estamos a pensar, nomeadamente, na educação de Pedro da Maia e na de Carlos.

Em relação à primeira ${ }^{(65)}$, deparam-se-nos os componentes técnico-literários e os vectores temáticos que atestam evidentes resquícios de vinculação naturalista: a representação omnisciente, a alusão a condicionamentos do meio cultural, a referência a características psico-somáticas de proveniência hereditária, etc. . Com Carlos da Maia e tendo em conta o que se expôs, encontramo-nos verdadeiramente perante estratégias de representação que, por obrigatoriamente conduzirem a uma configuração educacional e temperamental lacunar, apontam para novos caminhos de tratamento da personagem: os que valorizam o seu agir, quer dizer, a definição pela via da dinâmica individual de um conjunto de características que dispensam a tutela de uma qualquer entidade demiúrgica. Nem mais nem menos, afinal, do que aquilo que ocorre também com Gonçalo, nA Ilustre Casa de Ramires, ou com Jacinto, $n A$ Cidade e as Serras.

11. O que, em jeito de conclusão, podemos acrescentar a propósito das leituras sergianas da ficção de Eça, tem sobretudo o sabor de uma confirmação de notações disseminadas ao longo do que ficou escrito.

Em primeiro lugar, trata-se de sublinhar que o que se nos afigura precário ou infundamentado nas análises de Sérgio deve-se basicamente à desarticulação de dois componentes do seu processo ensaístico: por um lado, a preocupação com a vertente ético-ideológica das práticas culturais que suscitam a sua reflexão; por outro lado, a mera intuição da complexidade e peculiaridade de que se revestem essas práticas, quando se integram na esfera do estético-literário, com todas as inerentes implicações, não aprofundadas por Sérgio - do estatuto ontológico da fíccionalidade aos problemas levantados pelas estratégias pragmáticas do fenómeno literário, sem esquecer naturalmente as exigências técnico-compositivas e as virtualidades de elaboração estilística que o caracterizam. Não seria difícil, como se compreende, encontrar atenuantes para as limitações teórico-metodológicas do ensaísmo literário sergiano, limitações que tanto podem resultar da fixação num

${ }^{(* 5)}$ Cf. Os Maias, pp. 17 ss. 


\section{Antonio Sérgio}

certo projecto de reflexão cultural (de teor reformista e humanista mais do que estritamente crítico), como do estádio relativamente primordial em que, na época, se encontravam os estudos literários. Fiquemos, por agora, com o que se expôs: com a noção de que, apesar de tudo, o ensaísmo de Sérgio encerra, ainda hoje, abundantes potencialidades de reflexão pelo desafío que lança à discussão das teses que defendeu e à revisão das leituras que operou; e também isso constitui, inegavelmente, uma forma de correspondermos à lição de antidogmatismo que nos foi legada pelo autor dos Ensaios. 